\title{
Effect Analysis Of Benefit Perception, Ease Perception, Security And Risk Perception Of Merchant Interest In Using Quick Response Indonesia Standard (Qris)
}

\author{
Musa F. Silaen ${ }^{1 *}$, Sepbeariska Manurung ${ }^{2 *}$, Christine D. Nainggolan ${ }^{3 *}$ \\ ${ }^{1,2,3}$ Lecture, Sekolah Tinggi Ilmu Ekonomi Sultan Agung. \\ Pematangsiantar, North Sumatra 21118, Indonesia. \\ ${ }^{*}$ Corresponding author: \\ Email: timpdp2020@gmail.com
}

\begin{abstract}
The purpose of this research is to analyze the effect of benefit perception, ease perception, security and risk perception of merchant interest in using Quick Response Indonesia Standard (QRIS) simultaneously or partially. The research variables consist of, $X_{1}$ is benefit perception $X_{2}$ is easy perception, $X_{3}$ is security, $X_{4}$ is risk perception and $Y$ is merchant interest in using QRIS. Research data is Primary Data, obtained from the results of the distribution of questionnaires designed with the scale likert. The sample of the research was the merchant in pematangsiantar. Test Instruments using Test validity and reliability using SPSS. Technique Analysis, Multiple Regression, Classic Assumption Test, Hypothesis Test (Test $F$ and Test $t$ ). The result showed that benefit perception has no significant effect on merchant interest using QRIS, the easy perception has no significant effect on merchant interest using QRIS, the security has significant effect on merchant interest using QRIS and the risk perception has significant effect on merchant interest using QRIS.
\end{abstract}

Keywords: Benefit perception, easy perception, security, risk perception, merchant interest.

\section{INTRODUCTION}

The advancement of innovation today is increasingly bringing significant changes, especially in areas of business that have undergone many significant changes from scratch, such as direct sales to online sales [1] The rapid development in the technology industry forces people to be more familiar with financial transaction activities digitally (Financial Technology) one of them when making payment gateway transactions. Before the development of financial technology innovation today, e-commerce was first initiated and developed. The desire for a fast and secure payment system is the reason behind the implementation of digital financial transaction services [2]The most prominent development of financial technology (fintech) in Indonesia is the field of payments. Currently, the payment technique that is developing in the community is digital-based payments (cashless) [3] The application of e-money that has been used for online and offline payments can make it easier for merchants or merchants to transact. The cooperation between merchants and e-money providers will increase financial inclusiveness and encourage economic development [4]According to Bank Indonesia, non-cash payment techniques are divided into two, namely, e-money and e-wallet. E-money or electronic money is a chip-based payment technique (offline) while e-wallet or digital wallet, is a server-based payment technique (online), such as OVO, Go-Pay, Dana, Link-Aja, and i-saku [5] The advantage of paying using this digital wallet lies in its practicality, convenience and security. Some stages of payment are done simply. Until finally the transaction is declared successful, and the proof of transaction will be sent into the consumer transaction history automatically [2]

Quick Response Code (QR Code) is a development of technology used as a payment technique in digital wallets. By using one standard QR code, the provider of products and services (merchant) does not have to have a different type of QR Code from the publisher [6] With the presence of several types of digital wallet applications, merchants need to provide several QR code services as much as the number of digital wallet applications available to be scanned by each application. In the meantime, with different types of QR 
codes provided by the seller (merchant) causes consumers to have their own problems to scan QR codes, because each different QR code has terms and conditions.As the holder of the National Payment Gate (GPN) regulation, this makes Bank Indonesia need to have a system that can combine various instruments and payment channels nationally. To help realize this integrated system, Bank Indonesia sets a payment QR code standard in facilitating digital payment transactions in Indonesia called QRIS (Quick Response Indonesia Standard). QRIS is a QR code created by the joint regulator of the Indonesian Payment Systems Association (ASPI), which aims to securely streamline digital payment systems, support government productivity, and accelerate digital financial inclusion. QRIS is a QR code set up for different types of digital payment transactions. QRIS provides a more efficient choice of non-cash payment techniques [6]Likewise, the growth of digital wallets makes businesses in Pematangsiantar interested in using Quick Response Indonesian Standard (QRIS) in hopes of supporting increased sales. Based on information that researchers get from merchant correspondents in Pematangsiantar said that when making non-cash transactions with buyers, make transactions easier, simpler, efficient and faster.According to the Representative Office of Bank Indonesia Pematangsiantar that the number of merchant developments using QRIS has increased according to socialization carried out by payment system service providers (PJSP) to switch to using QRIS, can be considered in Figure 1 and 2 :

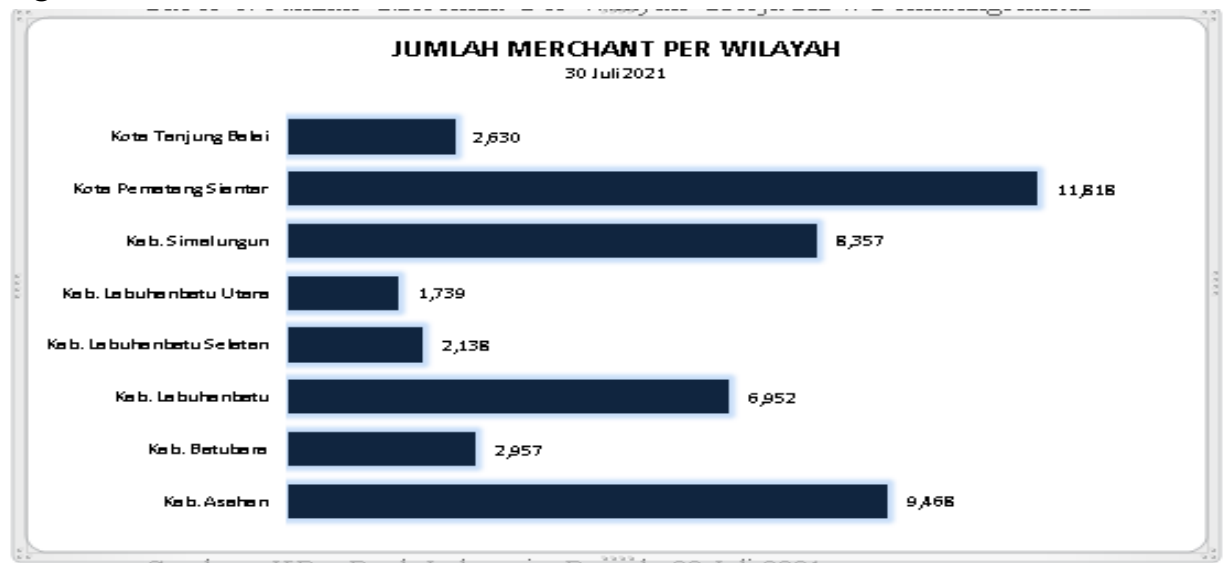

Fig 1. Number of Merchants Per Working Area KPw Pematangsiantar

\begin{tabular}{|c|c|c|}
\hline Provinsi/Kab/Kota & $\begin{array}{c}\text { Volume } \\
\text { Transaksi QRIS }\end{array}$ & $\begin{array}{c}\text { Nominal } \\
\text { Transaksi QRIS }\end{array}$ \\
\hline Kab Asahan & 18.950 & 1.617 .007 .177 \\
\hline Kab. Batu Bara & 6.082 & 504.519 .885 \\
\hline Kab. Labuhan Batu & 11.482 & 541.890 .080 \\
\hline Kab Labuhanbatu Selatan & 3.101 & 118.200 .185 \\
\hline Kab. Labuhanbatu Utara & 1.993 & 103.290 .535 \\
\hline Kab. Simalungun & 7.694 & 422.331 .561 \\
\hline Kota Pematang Siantar & 36.515 & 2.334 .104 .662 \\
\hline Kota Tanjung Balai & 14.997 & 454.850 .342 \\
\hline TOTAL & 100.814 & 6.096.194.42' \\
\hline
\end{tabular}

Fig 2. Development of QRIS Transaction Value and QRIS Transaction Volume

Based on figure 1 and 2 above, especially in the area of Pematangsiantar city total QRIS merchants reached 11,818 merchants, QRIS transaction volume reached 36,515 transactions, with 2,334,104,662 nominal QRIS transactions. The use of QRIS has become a positive trend lately for businesses and consumers. Given its benefits in helping non-cash transaction processes more efficiently, the use of QRIS by merchants will be able to help improve their business performance, especially during pandemics like today.Based on the results of research and interviews conducted in August 2021, researchers found several things, among others, the benefits derived from the use of QRIS as a non-cash payment tool that makes transactions more effective, but in this study researchers found barriers that led to low utilization of non-cash payments by consumers or the general public and the absence of information about QRIS to merchants and the public.From the description is the motivation of the purpose of this study to find out the tendency or 
interest of the community, especially for merchants towards QRIS digital payment instruments in the city of Pematangsiantar. To see if the merchant is interested in or not using QR codes as a digital means of payment, and if the merchant has an interest in the use of QR codes, what factors are behind the merchant's interest, whether the perception of convenience, perception of trust, perception of usefulness or perception of risk. With this, the author is interested in researching more about the phenomenon that occurs.Previous research that is in accordance with this study is as follows, [2] shows that the perception of ease, trust, expediency and risk affects consumer preferences using QRIS as a means of payment simultaneously and partially. [7] show that habit, social influence, and effort expectancy influence behavior intentions. [8] stated that usability, convenience and security have a significant influence on the interest in using E-Money simultaneously, convenience and security have a significant influence on the interest in using E-Money partially. [9] states that usability, convenience and security have a significant effect on the interest in using E-Money simultaneously, convenience and security have a significant influence on the interest in using E-Money partially.

\section{METHODS}

Interest is a deliberately occurring tool and concentration of interest or mental that causes individuals to have pleasure or not towards an object with full security and depend on ability and environment [10] Opinion [11] behavioral intention is the desire or interest of individuals to perform certain behaviors. Interest in this is connoted by the merchant's desire to use QRIS as a digital instrument, for various reasons such as the perception of ease of use, the belief that transacting using QRIS is safe, using QRIS provides many benefits or risk levels in using QRIS as a relatively low payment method.Perceived Usefulness is the extent to which an individual accepts that utilizing a technology will increase the ability of his work [11]

The perception of benefits in this case is connoted by the merchant's wishes for various reasons providing many benefits in using QRIS as a digital payment method, such as more effective and efficient transactions, errors in transactions can be minimized, and no difficulty in converting. This is in accordance with the opinion [12] which states that the perception of benefits is that a person's confidence in a technology will greatly affect the improvement of its performance if it is beneficial for users of that technology. The benefit in using e-money is the usability value that will be obtained or expected by e-money users in making various transactions. From the above explanation it can be concluded that the first hypothesis is as follows:

\section{$\mathrm{H}_{1}$ : Perception of benefits has a significant effect on merchant interest in using QRIS applications.}

Perceived Ease of Use [11] ease of use is defined as the extent to which an individual's trust utilizing technology will be free from effort. [12] defines perceived Ease of Use as a belief in ease of use, particularly how much users accept that the technology/system can be used effectively and problem-free. The perception of ease of use in this case is connoted by the desire of merchants for various reasons to provide many eases of use in using QRIS as a digital payment tool, such as being able to relate to mobile commerce technology and does not require large efforts, easy to understand its use and more efficient. This is in line with this research connoted the desire of merchants for various reasons to provide many easy uses in using QRIS as a digital payment tool, such as being able to relate to mobile commerce technology and does not require large efforts, easy to understand its use and more efficient. This is in line with research [13] found that the perception of ease of use, perception of cost and amount of information available related to digital payments have an important effect on customer intentions in using digital payments. From the above explanation it can be concluded that the second hypothesis is as follows:

\section{$\mathrm{H}_{2}$ : The perception of ease of use has a significant effect on the interest of merchants in using QRIS applications.}

Security [14] is how we can prevent fraud (cheating) or detect fraud on a system based on information. Where the information itself has no physical meaning. The perception of security in this case is connoted is to provide security when transacting in using QRIS as a digital payment tool. According to [15] security variables are an important factor in influencing an individual's interest in reusing banking services [including e-money], the higher the level of security that the company provides to consumers/ customers, the 
more strengthen not only interest but also reuse the services provided. This is in line with research [16] security has a significant effect on customer interest using mobile banking at PT Bank Rakyat Indonesia (Persero) Tbk Semarang Pandanaran Branch. From the explanation above, the third hypothesis can be concluded as follows:

\section{$\mathrm{H}_{3}$ : Security perception has a significant effect on merchant interest in using QRIS applications.}

Perceived risk [11] implies a person's subjective beliefs about the negative consequences of choices made by consumers. According to [17], risk perception is a perception of uncertainty and the unintended consequences of the use of a product or service. Risk perception significantly affects the level of trust. The smaller an individual's risk perception, the greater his or her level of trust, and vice versa. This is in accordance with research by [18] that risk perception has a significant positive influence on QRIS-based emoney usage decisions. From the explanation above, the first hypothesis can be concluded as follows:

\section{$\mathrm{H}_{4}$ : Risk perception has a significant effect on merchant interest in using QRIS applications.}

Descriptive-quantitative research types. The independent variables or free variables are $\mathrm{X} 1=$ Benefit Perception, X2 = Ease of Use Perception, X3 = Security, X4 = Risk Perception, and dependent variables or bound variables are $\mathrm{Y}=$ Merchant interest in using QRIS applications. The research data is primary data, obtained from the results of the distribution of questionnaires designed on a linkert scale. The Research Sample was a Merchant in Pematangsiantar selected numbering 45 respondents. Instrument Test and Validity Tests for validity and reliability using SPSS. Analytical Technique, Multiple Regression, with regression equations: $\mathrm{Y}=\mathrm{a}+\mathrm{pX} 1+\mathrm{pX} 2+\mathrm{pX} 3+\mathrm{s}$. Classical Assumption Test (Data Normality, Multicolonierity Test, and Heteroskedasitistas Test), Hypothesis Test (Test $F$ and Test $t \alpha=0,05$ ).

\section{RESULTS OF RESEARCH AND DISCUSSION}

This research uses data quality tests or instrument tests that include validity and reliability tests. The test of validity and reliability of the instrument is the perception of benefits, perception of convenience, safety, perception of risk and interest in the use of QRIS. The results of the validity and reliability test can be shown in the table below:

Table 1. Results of Test Validity and Reliability of Benefit Perception Instruments $\left(\mathrm{X}_{1}\right)$, Ease Perception $\left(\mathrm{X}_{2}\right)$, Security $\left(\mathrm{X}_{3}\right)$, Risk Perception $\left(\mathrm{X}_{4}\right)$ and Interest $(\mathrm{Y})$

\begin{tabular}{lccccc}
\hline Variable & $\begin{array}{c}\text { Correlation } \\
(\mathbf{R})\end{array}$ & Meaning & $\begin{array}{c}\text { Value of } \\
\text { Cronbach's } \\
\text { Alpha }\end{array}$ & $\begin{array}{c}\text { N of } \\
\text { Item }\end{array}$ & Meaning \\
\hline Benefit Perception & 0,612 & Valid & 0,673 & 45 & Reliable \\
Ease Perception & 0,629 & Valid & 0,660 & 45 & Reliable \\
Security & 0,796 & Valid & 0,646 & 45 & Reliable \\
Risk Perception & 0,801 & Valid & 0,680 & 45 & Reliable \\
Interest & 0,748 & Valid & 0,685 & 45 & Reliable \\
\hline
\end{tabular}

Source: Data process, SPSS (2021)

Based on table 1. above it is shown that all question items contained in the research instrument are valid and reliable. This instrument is said to be valid with the value of each variable greater than the $\mathrm{r}_{\text {tabel }}$ value where the $\mathrm{r}_{\text {tabel }}$ value is $0.294(\mathrm{~N}-2$, and alpha 5\%). This research instrument is said to be reliable because the correlation coefficient value $r$ alpha cronbach of each variable is greater than the standard reliability value of 0.60 .

\section{Normality Test}

Normality tests are conducted to find out whether the data is normal or not. In this study the normality test used was a one sample kolmogorov-smirnov test. Where if sig value. $>$ alpha, the data is normal. The significance level used is $5 \%$ or 0.05 . Data Normality Test

Table 2. Data Normality Test

One-Sample Kolmogorov-Smirnov Test

\begin{tabular}{lc}
\hline & Unstandardized Residual \\
\hline $\mathrm{N}$ & 45
\end{tabular}




\begin{tabular}{lll} 
Normal Parameters ${ }^{\mathrm{a}, \mathrm{b}}$ & Mean &, 0000000 \\
& Std. Deviation &, 38108602 \\
Most Extreme Differences & Absolute &, 177 \\
& Positive &, 114 \\
Kolmogorov-Smirnov Z & Negative &,- 177 \\
Asymp. Sig. (2-tailed) & & 1,190 \\
\hline
\end{tabular}

Source: Data process, SPSS (2021)

Based on the results of one sample of kolmogorov smirnov test it is known that the value of asymp. Sig (2tailed) is 0.118 or $0.118>0.05$ so it can be concluded that the data in this research is normal distribution.

\section{Multicollinearity Test}

Multicollinearity tests are used to test whether there is a correlation between independent variables. A good regression model is one in which there is no correlation between independent variables. Multicollinearity tests used are with TOL (Tolerance) and VIF (Inflation Factor Variant). The results of the multicollinearity test are presented in the following table:

Table 3. Multicollinearity Test

\begin{tabular}{lccc}
\hline & Variabel & Tolerance & VIF \\
\hline Benefit Perception & & 0,668 & 1,497 \\
Ease Perception & & 0,371 & 2,697 \\
Security & 0,379 & 2,636 \\
Risk Perception & & 0,955 & 1,047 \\
\hline
\end{tabular}

Source: Data process, SPSS (2021)

Based on the results of the multicollinearity test in table 3. above, the benefit perception TOL value is 0.668 , the perception of convenience is 0.371 , the security is 0.379 and the risk perception is 0.995 . Of the four variables, the TOL value is greater than 0.10 which indicates that the four variables do not experience symptoms of multicollinearity. The VIF value of the perception of benefits is 1,497, the perception of convenience is 2,697 , the security of 2,636 and the risk perception is 1,047 . The VIF value of the four independent variables is less than 10 , so it was concluded that the four independent variables did not experience symptoms of multicollinearity.

\section{Heteroskedasticity Test}

Heteroskedasticity tests are used to test the inequality of variance from residual one observation to another. A good regression model is that there are no symptoms of heteroskedasticity or homoskedastisity. Scatter plot charts were used to test whether or not heteroskedasticity occurred in this study. The results of heteroskedasticity testing are as follows:

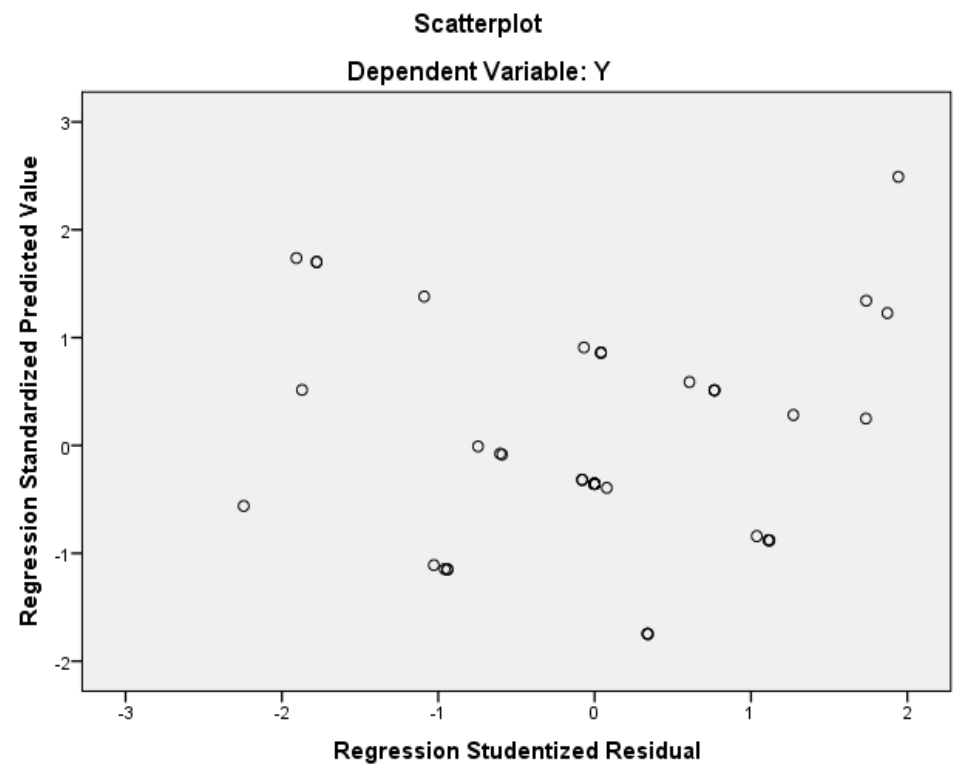

Fig 3.Test heteroskedastisity

http://ijstm.inarah.co.id 
Based on the results of heteroskedasticity testing it was found that there were random spreading plots with unclear patterns located above or below the number 0 on the residual studentized regression axis, thus it was said that there were no symptoms of heteroskedasticity in regression models.

Table 4. Multiple Linear Regression Test Results

\begin{tabular}{llccc}
\hline \multicolumn{1}{c}{ Model } & \multicolumn{2}{c}{ Unstandardized Coefficients } & \multicolumn{2}{c}{ Standardized Coefficients } \\
& B & Std. Error & Beta \\
\hline \multirow{4}{*}{1 (Constant) } &,- 356 & 1,021 & \\
Benefit Perception &,- 032 &, 059 &,- 044 \\
& Easy Perception &, 062 &, 082 &, 083 \\
& Security &, 456 &, 136 &, 367 \\
& Risk Perception &, 352 &, 033 &, 739 \\
\hline
\end{tabular}

Source: Data process, SPSS (2021)

From the results of regression testing obtained the equation $\mathrm{Y}=-0.356-0.032 \mathrm{X}_{1}+0.062 \mathrm{X}_{2}+0.456 \mathrm{X}_{3}+$ $0.352 \mathrm{X}_{4}$, The value of the regression coefficient for the benefit perception variable by -0.032 which means that in the event of an increase in the perception of benefits by 0.032 will reduce interest by $0.032 \%$. The regression coefficient value for the ease perception variable is 0.062 which means that in the event of an increase in the perception of ease of 0.062 will increase interest by $0.062 \%$. The regression coefficient value for the security variable is 0.456 which means that in the event of an addition of security of 0.456 it will increase interest by $0.456 \%$. The regression coefficient value for the risk perception variable is 0.352 which means that in the event of an increase in risk perception of 0.352 will increase interest by $0.352 \%$.

Table 5. Test Results F

\begin{tabular}{llccccc}
\multicolumn{7}{c}{ ANOVA $^{\mathbf{a}}$} \\
\hline & Model & Sum of Squares & df & Mean Square & F & Sig. \\
\hline & Regression & 28,854 & 4 & 7,214 & 45,156 &, $000^{\mathrm{b}}$ \\
& Residual & 6,390 & 40 &, 160 & & \\
& Total & 35,244 & 44 & & & \\
\hline
\end{tabular}

Source: Data process, SPSS (2021)

Based on table 5, it is known that the Fhitung value of $>$ Ftabel $(45,156>2.61)$ or the significance of $<0.05$ $(0.000<.005)$, meaning that together the perception of benefits, perception of convenience, security and risk perception have a significant effect on the interest of merchants in using QRIS applications.

Table 6. Test Results $t$

\begin{tabular}{llcc}
\hline \multicolumn{1}{c}{ Model } & $\mathrm{t}$ & Sig. \\
& & & \\
\hline & (Constant) & &, 729 \\
Benefit Perception &,- 349 &, 593 \\
& Easy Perception &,- 538 &, 455 \\
& Security &, 755 &, 002 \\
& Risk Perception & 3,356 &, 000 \\
\hline
\end{tabular}

Source: Data process, SPSS (2021)

Based on table 6 , it is known that the value of the perception of benefits is $t_{\text {hitung }}<t_{\text {tabel }}(-0.538<2.02108)$ or significance $>0.05(0.593>0.005)$. This means that partially $\mathrm{X}_{1}$ has no significant effect on $\mathrm{Y}$, it is concluded that $\mathrm{H}_{1}$ : perception of benefits has a significant effect on merchant interest in using QRIS applications, rejected because it is not proven based on the results of the $t$ test.

The perception value of convenience is $t_{\text {hitung }}<t_{\text {tabel }}(0.755<2.02108)$ or significance $>0.05(0.455>$ 0.005). This means that partially $\mathrm{X}_{2}$ has no significant effect on $\mathrm{Y}$, it is concluded that $\mathrm{H}_{2}$ : the perception of ease has a significant effect on the interest of merchants in using QRIS applications, rejected because it is not proven based on the results of the $t$ test. The security value is $t_{\text {hitung }}<t_{\text {tabel }}(3.356>2.02108)$ or significance $<$ $0.05\left(0.002<0.005\right.$. This means that partially $\mathrm{X}_{3}$ has a significant effect on $\mathrm{Y}$, it is concluded that $\mathrm{H}_{3}$ : Security has a significant effect on the interest of merchants in using QRIS applications, accepted because it is proven based on the results of the test $t$. The risk perception value is $t_{\text {hitung }}<t_{\text {tabel }}(10,730>2.02108)$ or the significance of $<0.05(0.000<0.005)$. This means that partially $\mathrm{X}_{4}$ has a significant effect on $\mathrm{Y}$, it is 
concluded that $\mathrm{H}_{4}$ : Security has a significant effect on merchant interest in using QRIS applications, accepted because it is proven based on the results of the $t$ test.

\section{CONCLUSIONS}

The test in this study was to find out whether there was an influence on benefit perception, ease perception, security and risk perception of merchant interest in the use of QRIS. After various discussions, it was concluded that:

1. The results of the classical assumption test explain that the instrument used in the study is valid and reliable. The regression model used in the study was also declared normal and free from symptoms of heteroskedasticity and multicollinearity.

2. The perception of benefits $\left(\mathrm{X}_{1}\right)$ shows a regression coefficient value of -0.032 with a significant value of 0.593 . This suggests that the perception of benefits negatively and insignificantly affects the merchant's interest in using the QRIS application.

3. Ease perception $\left(\mathrm{X}_{2}\right)$ shows a regression coefficient value of 0.062 with a significant value of 0.455 . This shows that the perception of ease has a positive and insignificant effect on the interest of merchants in using QRIS applications.

4. Security $\left(X_{3}\right)$ indicates a regression coefficient value of 0.456 with a significant value of 0.002 . This suggests that the perception of benefits negatively and insignificantly affects the merchant's interest in using the QRIS application.

5. Risk perception $\left(\mathrm{X}_{4}\right)$ shows a regression coefficient value of 0.352 with a significant value of 0.000 . This suggests that the perception of benefits negatively and insignificantly affects the merchant's interest in using the QRIS application.

\section{ACKNOWLEDGMENT}

As a team of beginner lecturer researchers, we are very grateful for the trust that LLDIKTI has given us material and moral support so that we can complete this research. We are also grateful to the chairman of Sekolah Tinggi Ilmu Ekonomi Sultan Agung who has given us the opportunity to follow the research of beginner lecturers and support us fully. We thank to our surveyor team who help us in collect data process and can be completed properly. And especially to the fellow researchers, thank you for the time, effort, and thoughts that have been given so that this research can be completed properly. Finally, hopefully this research can be useful for all parties in need.

\section{REFERENCE}

[1] M. I. Hardiky, D. K. Nova, A. Rahmadewi, and N. Kustiningsih, "Optimalisasi Digital Payment Sebagai Solusi Pembayaran UMKM Roti Kasur,” JRE J. Ris. Entrep., vol. 4, no. 1, pp. 44-48, 2021, doi: doi:10.30587.jr.ev4i1.2193.

[2] O. B. Saputri, "Preferensi konsumen dalam menggunakan quick response code indonesia standard (qris) sebagai alat pembayaran digital," KINERJA J. Ekon. Manaj., vol. 17, no. 2, pp. 237-247, 2020.

[3] R. Mayanti, "FAKTOR-FAKTOR YANG MEMENGARUHI PENERIMAAN USER TERHADAP PENERAPAN QUICK RESPONSE INDONESIA STANDARD SEBAGAI TEKNOLOGI PEMBAYARAN PADA DOMPET DIGITAL," J. Ilm. Ekon. Bisnis, vol. 25, no. 2, 2020.

[4] J. E. Sihaloho, A. Ramadani, and S. Rahmayanti, "Implementasi Sistem Pembayaran Quick Response Indonesia Standard Bagi Perkembangan UMKM di Medan Josef," J. Manaj. Bisnis, vol. 17, no. 2, pp. 287-297, 2020.

[5] V. D. Devita, "E-Wallet Lokal Masih Mendominasi Q2 2019-2020," iPrice, 2020. .

[6] I. W. A. Setiawan and L. P. Mahyuni, "QRIS di Mata UMKM: Eksplorasi Persepsi Dan Intensi UMKM Menggunakan QRIS,” E-jurnal Ekon. dan Bisnis, vol. 9, no. 10, pp. 921-946, 2020, doi: https://doi.org/10.24843/EEB.2020.v09.i10.p01.

[7] M. S. Gayatrie, A. Kusyanti, and M. C. Saputra, "Analisis penerimaan OS Windows 10 dengan Unified Theory of Acceptance and Use of Technology (UTAUT2).," J. Pengemb. Teknol. Inf. dan Ilmu Komput., vol. 1, no. 6, pp. 514-523, 2017.

[8] S. S. Utami and B. Kusumawati, "Faktor-Faktor Yang Mempengaruhi Minat Penggunaan E-Money (Studi pada 
Mahasiswa STIE Ahmad Dahlan Jakarta),” J. Balanc. Econ. Business, Manag. Account. J., vol. 18, no. 2, pp. 29-41, 2017.

[9] R. Dzulhaida and R. R. W. Giri, “Analisis Minat Masyarakat Terhadap Penggunaan Layanan E-Money di Indonesia Dengan Menggunakan Model Modifikasi Unified Theory Of Acceptance And Use Technology 2 (UTAUT 2)," Majalah UNIKOM, Bandung, pp. 155-166, 2017.

[10] J. Sebastian, "Analisis Faktor-Faktor Yang Mempengaruhi Minat Masyarakat Menggunakan E-Money Di Kecamatan Medan Belawan," Repos. Institusi Univ. Sumatera Utara, 2020.

[11] H. Jogiyanto, Sistem informasi Keperilakuan. Yogyakarta: Andi Offset, 2007.

[12] F. D. Davis, "Perceived Usefulness, Perceived Ease of Use, and User Acceptance of Information Technology," MIS Q., vol. 13, no. 3, pp. 319-340, 1989, doi: https://doi.org/10.2307/249008.

[13] P. C. Ezeh and N. Nwankwo, "Factors that Influence the Acceptance of Mobile Money in Nigeria," J. Res. Mark., vol. 8, no. 2, p. 684, 2018, doi: https://doi.org/10.17722/jorm.v8i2.217.

[14] B. Rahardjo, Keamanan Sistem Informasi Berbasis Internet. 2005.

[15] Ahmad and B. S. Pambudi, "Pengaruh Persepsi Manfaat, Persepsi Kemudahan, Keamanan Dan Ketersediaan Fitur Terhadap Minat Ulang Nasabah Bank Dalam Menggunakan Internet Banking (Studi Pada Program Layanan Internet Banking BRI)," Competence J. Manag. Stud., vol. 8, no. 1, pp. 1-11, 2014, doi: DOI: https://doi.org/10.21107/kompetensi.v8i1.589.

[16] M. O. Pranoto and R. G. Setianegara, “Analisis Pengaruh Perspsi Manfaat, Persepsi Kemudahan, Dan Keamanan Terhadap Minat Nasabah Menggunakan Mobile Banking ( Studi Kasus PT Bank Rakyat Indonesia (Persero) Tbk Cabang Semarang Pandanaran. Persero," Keunis Maj. Ilm., vol. 8, no. 1, 2020, doi: DOI:10.32497/keunis.v8i1.2117.

[17] M. S. Featherman and P. A. Pavlou, "Predicting E-Services Adoption: A Perceived Risk Facets Perspective," Int. J. Hum. Comput. Stud., vol. 59, no. 4, pp. 451-474, 2003, doi: https://doi.org/10.1016/S10715819(03)00111-3.

[18] H. A. Ningsih, E. M. Sasmita, and B. Sari, “ANALISIS PENGARUH PERSEPSI MANFAAT, PERSEPSI KEMUDAHAN PENGGUNAAN, DAN PERSEPSI RISIKO TERHADAP KEPUTUSAN MENGGUNAKAN UANG ELEKTRONIK BERBASIS QUICK RESPONSE CODE INDONESIAN STANDARD (QRIS) DI KALANGAN MAHASISWA UPI Y.A.I,”IKRAITH, vol. 4, no. 2, 2020. 